\title{
Greening up and the Political Manifestos: A Review of Political Party Manifestos on Issues of the Environment in Malawi
}

\author{
Aeron Madalitso Anastanzio Nahuku ${ }^{1, *}$, Alinune Musopole ${ }^{1}$, Harrison Bokola ${ }^{2}$, \\ Doreen Mdzeka Nahuku ${ }^{3}$ \\ ${ }^{1}$ Department of Biomedical Sciences, Faculty of Biomedical Sciences and Health Professions (BMSHP), University of Malawi, Blantyre, \\ Malawi \\ ${ }^{2}$ Department of Physics and Biochemical Sciences, Faculty of Applied Sciences, University of Malawi, Blantyre, Malawi \\ ${ }^{3}$ Department of Language and Communications, Faculty of Education and Media Studies, University of Malawi, Blantyre, Malawi
}

\section{Email address:}

anahuku@medcol.mw (A. M. A. Nahuku)

${ }^{*}$ Corresponding author

\section{To cite this article:}

Aeron Madalitso Anastanzio Nahuku, Alinune Musopole, Harrison Bokola, Doreen Mdzeka Nahuku. Greening up and the Political Manifestos: A Review of Political Party Manifestos on Issues of the Environment in Malawi. International Journal of Environmental Protection and Policy. Vol. 8, No. 5, 2020, pp. 94-99. doi: 10.11648/j.ijepp.20200805.11

Received: September 16, 2020; Accepted: September 29, 2020; Published: October 7, 2020

\begin{abstract}
Environmental mismanagement or inequality, or both are a cause of havoc and risk vulnerability to most countries across the globe with the worst hit being the developing ones. Issues of water and food supply crises, extreme energy volatilities, greenhouse gas emissions and its impacts, severe income disparity, chronic fiscal imbalances among others are such examples of risks encountered by countries. Lack of political parties' substantive ideologies, and that their policy positions are almost identical and often times centered within their political will, has seen the environment being crippled with little to no attention within their manifestos. This study involved a review of 5 political party manifestos in the Malawi 2019 Tripartite Election (TPE) by utilizing the Manifesto Research Group (MRG) methodology of counting the number of environmental sentences in party manifestos for national elections. Total number of statements with those for the environment were compared. Quantitative data management used Microsoft excel and IBM $^{\circledR}$ SPSS $^{\circledR}$ statistics version 23.0 for organization and to further analyse and answer the research question(s). From a total of 5 manifestos whose statement were studied especially on the issues of the environment, a revelation showed that only $60 \%$ of the manifestos had a standalone section with the majority of those with sections/chapters registering less than 10 statements on issues of the environment as compared to other sections like for example health and sustainable economic growth. $33 \%$ of the available standalone sections had no statement as a commitment in combating issues of the environment. Lack of commitment by parties has been displayed through their manifestos in helping to address problems that surround our environment by having scanty or no section at all. Having an environmental section/chapter with not even one statement on it has evidenced lack of seriousness and prioritization by parties. This just shows that there is little commitment by parties to fight issues of the environment that are a cause of most economic havocs. Parties in Malawi, must therefore consider the environment seriously right at the onset of manifesto development in order to inform proper policy development and implementations.
\end{abstract}

Keywords: Environment, Manifesto, Political Party, Political Will, Policy

\section{Introduction}

Most current serious problems that the world is in today have ranged from water and food supply crises, extreme energy volatilities and rising prices of food, rocketing greenhouse gas emissions and its impacts, severe income 
disparity, chronic fiscal imbalances and terrorism [17]. According to the World Economic Forum (WEF) these problems are believed to stem from environmental mismanagement or inequality, or both which makes developing countries most vulnerable to numerous risks [22]

The importance of political parties during their campaign to take into account such problems that puts countries exceptionally most venerable to such risks needs to be emphasized. It is currently traditional across the globe that party campaigns are stylized with a version of party democracy that puts great emphasis on parties' policy programs as structuring the campaign, voters' choices, party coalition building, and government policy [7].

Then the parties fight elections, rallying behind their manifestos that lays down policy priorities and positions, and a team of leaders committed to them. The victorious party takes government office and switches into implementation of its policy program outlined in their sold manifesto that can range from, economic development, sustainable energy sources, women empowerment as well as how to keep the environment sustainable among others [7].

Now when a political party(s) prepares a manifesto, so defined as, a published declaration of intentions, motives, or views of political organizations which generally present the level of attention that a party, organization or an individual will pay to an issue and how to address it [20], must carefully consider environmental mismanagement and inequality currently at the hub of igniting current difficult to control risks These are important and central elements for comprehending public policy development in relation to those matters by which that a political party, individual or organization, should be voted and trusted into power with and help it reduce the risks on its economy.

All over, arguments are that political parties lack substantive ideologies, and that their policy positions are almost identical and often times party centered within their political will [14]. Their rhetoric tools in political discussion and political will, remains ambiguous as a concept for most parties [18] that uses ideological conceptual drives to impress the electorate to amass votes.

Never the less, most authors' proposition on a pragmatic and systematic approach, defining political will shows that it's just a ghost in the machine of politics and the motive force that generates political action within political parties [18]. This revolves around the center of power and to political decision making as the key actors in good governance [1]. Interestingly, the political elites, represent voters' interests and implement their collective will [18] and at times sometimes not.

Just as many countries, Malawi as a country needs to experience sustainable economic growth and alleviate poverty by conserving its valuable environmental resources as the livelihoods of its population are largely dependent on natural resources [6]. Because of this, government must and has taken various measures to safeguard the country's natural resource base for example inter alia, the enactment of the Environmental Management Act of 1996; the Forestry Policy of 1996; the Land Policy of 2002; the Water and Sanitation
Policy of 2005; and the Biodiversity Strategy and Action Plan of 2008.

According to Ryan (2017), political parties' main function is to articulate and represent the interests and visions of different social sectors and actors, with the expectation of impacting on government's agenda and policies [20]. Just as others, manifesto statements on environment, needs thorough articulation by political parties in Malawi as observed across the globe targeting numerous issues that are linked to potential dangers of the environment.

These parties' ideological frameworks can clearly be a range of possible policy instruments that are considered legitimate or more appropriate in addressing environmental and climate change issues [20]. According to Elischer (2012), party ideologies are not seen to differ much and most election campaigns are characterized by slogans with which anyone can empathize such as demands for better infrastructure, more inclusive health care and education facilities, and anticorruption statements but not much on the environment [8].

Political parties have an influence on attitudes of their members and the public at large on a variety of issues. Through party discipline, members are expected to adhere to party policies. A party that has environmental issues as one of its concerns will have its members viewing such issues in a similar manner. Political parties play a role in shaping attitudes of their members but also the public [4].

Political parties across the globe for example in Asia have been seen with positive initiatives in including environmental issues in their manifestos. For example, on one hand, the Bharatiya Janata Party (BJP) in its 2014 election manifesto, put climate change mitigation initiatives while working with global communities on this matter as its main agenda meant to encourage cleaner production, promoting cleaner fuels, concept of proactive carbon credits, pollution control, social forestry, green buildings, promotion of research and development in environment technologies and a mechanistic approach for protection and preservation of wildlife. On the other hand, the Aam Aadmi Party (AAP) promised to ensure that while ownership of major natural resources will be vested in the state, the minor minerals and forest produce, should belong to the local communities [10].

In Europe especially United Kingdom (UK), on the environment, as a party's political issue, Liberal Democrats have consistently been giving more mentions to the environment in each of their manifestos since 1979 [19]. In the year 2019, European People's Party (EPP) manifesto for the European Parliament (EP) elections 2019, has been adopted at the EPP political assembly on the 20th of March 2019 with some interesting section on the environment. Notable one among the many was its commitment in making sure that it continues to defend the Paris Climate agreement based on scientific evidence and remain the global leader in combatting climate change [9].

In Africa too, specifically in Namibia on Water, "a commodity needed to be preserve to drive Namibia's growth" the Popular Democratic Movement (PDM) previously known 
as the Democratic Turnhalle Alliance (DTA), emphasized the need to encourage efficient use of water, water conservation, recycling and rain water harvesting, sewage treatment plants to prevent pollution of rivers, desalination plants for drinking water supply in coastal cities and inter-linking of rivers based on feasibility [5]. It also made its proposal to encourage and incentivize innovative garbage disposal and waste management practices as a result of increased quantity and complexity of generated waste as evidenced by United Nations Economic and Social Commission for Asia and the Pacific [21].

Within the sub-Saharan countries, a lot have happened ranging from floods, drought and food insecurities as well as wild fires including the current cyclone Idae that has caused much devastation in Malawi, Mozambique and Zimbabwe [12]. According to Budge and Laver (1993), Franzmann and Keiser (2006), Klengmann et al, (1994) and Ray (2007) in [13], the importance of making content analysis in political party programs or manifestos is quite huge.

Firstly, manifestos act as vehicles used to inform voters about party's preferences and proposals in order to answer society's issues of concern. Secondly, they provide the capability of political parties to sort citizens' demands by selecting and aggregating them into coherent policy packages. Additionally, these documents quite often serve as election propagandas since they are instruments of communication with voters but also commitments for parliamentarians once elected among others. Across the globe, the content analysis of political party's manifestos has unraveled critical commentary on education, health, politics, infrastructure development, economic development as well as on the issues of the environment.

Political parties have an influence on public policy. Parties with a great interest in environmental matters will ensure that policies implemented by government do not endanger the environment. Political decision making process is significant in ensuring proper protection and improvement of the environment [13]. As such, political parties have a role in making sure that government develops environmental policies it signed [3].

Despite efforts by government to address other major issues, the degradation of natural resources continues to be a major threat to the social and economic development of Malawi [6]. Environmental issues must therefore be taken with prominence by political parties when developing their manifestos knowing that sustainable economic growth and poverty alleviation depends on valuable environmental resources that Malawi has as the livelihoods of its population explicitly dependent on natural resources. Studies made in Malawi meant to critically analyze how political parties makes a direct confrontation on environmental issues by precisely including chapters and sections with environmental statements associated with them have proven to be unavailable or scanty.

Therefore, this study was meant to investigate, by counting number of statements that describe how parties incorporated environmental issues by presenting chapters and/or clear sections with statements specifically to do with the environment in the May, 2019 Tripartite Elections (TPE) manifestos as driving forces for policy development and implementation in order to reduce its concerns on the society.

\section{Methodology}

This study was a desk review, quantitatively descriptive in nature and utilized a total of five political party manifestos out of the seven that contested in the May 21, 2019 Malawi Tripartite Elections (TPE). The study used manifesto documents for the Democratic Progressive Party (DPP), United Democratic Front (UDF), Malawi Congress Party (MCP), Umodzi Party (UP) as well as the newly formed United Transformation Movement (UTM) that contested in the 2019 TPE.

Mbakuwaku Movement for Development (MMD) as well as the Independent candidate's manifestos were not part of this study as they were not easily accessible like the others. It involved reading through these accessed political party policy driving documents in order to identify environmental chapters, sections and their statements with possible policy evolvement as commitments to spear head issues of the environment when such a party gets voted into power to form the new government.

These parties were selected purposively based on the availability of the prepared and launched manifesto documents during the May 21, 2019 TPE campaigns. The reading through of the documents, made conclusions as well as recommendations was entirely objective and not biased in any way. It was not based in anyway, on particular political organization affiliation by the researcher(s), how important the party is to the researcher(s) or its chances of winning the past TPE basing on its popularity.

Neither was it based on ongoing projects by parties, election research findings and projections in favor of the parties nor on available pastoral or prophetic messages made to political party leaders among others. These documents were original copies made available by parties and circulated electronically in different platforms including the social media.

The study utilized a methodology previously used by Manifesto Research Group (MRG) by counting the number of sentences in party manifestos for national elections of all significant parties from over 25 countries across the world. The MRG did this over a period 50 years from 1945 to 1998 and grouped them into one of 54 designated policy categories [15] which was not done in this study.

Counting the number of lines or statements a political party included in its manifesto as an indication to create and take responsibility of the current environmental issues is quite important. Often times it provides an indication of parties' readiness to develop and implement environmental policies that will help improve the environment but also change the perspectives of the society which enhances its responsibility on the environment.

These environmental concerns do range from agriculture, climate change, natural disasters, construction, industrial 
activities, waste management, transportation and engineering just to mention a few. In order to answer this study's question(s) and reach a conclusive generalization, Microsoft (MS) Excel and IBM ${ }^{\circledR}$ SPSS ${ }^{\circledR}$ statistics version 23.0 was used to analyze the data collected.

\section{Results}

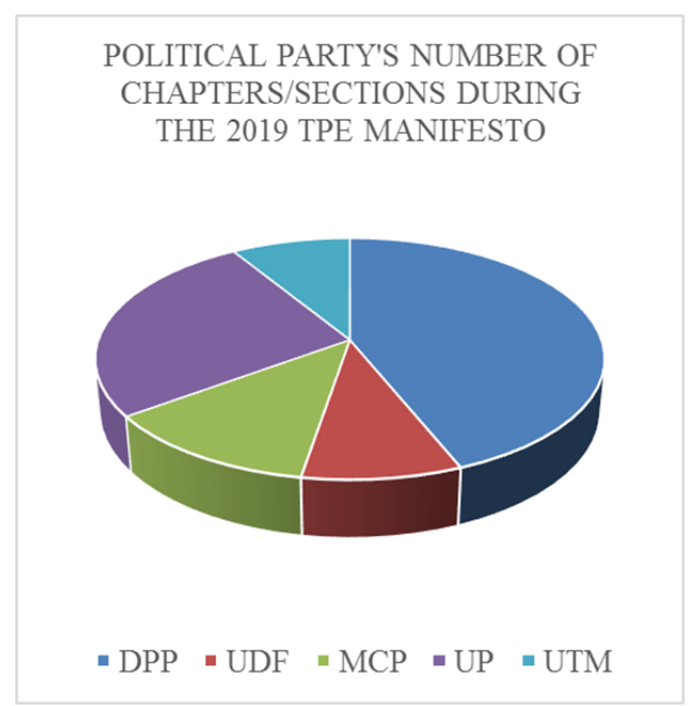

Figure 1. Number of Chapters/Sections Presented in the 2019 TPE Manifestos.

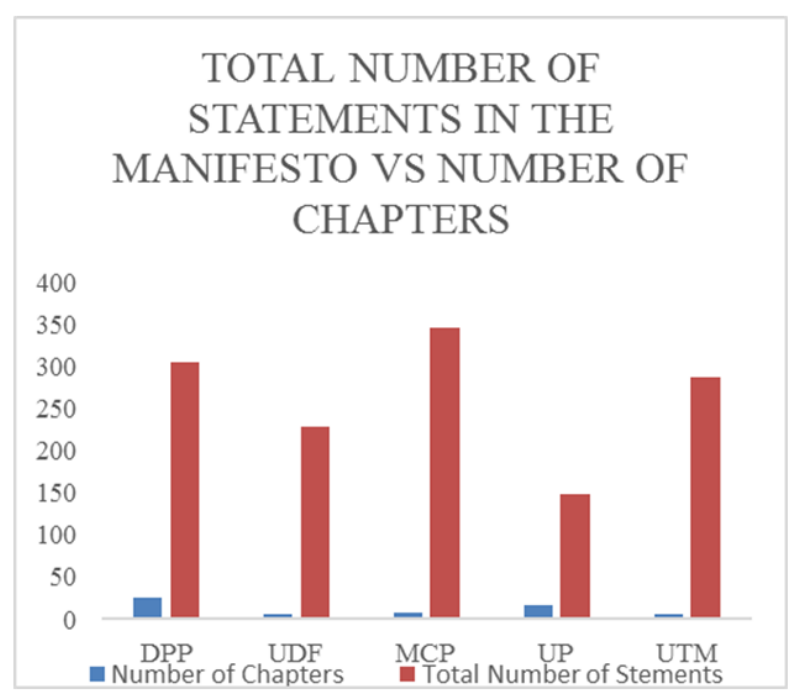

Figure 2. Total number of Statements made vs Number of chapters for each party in the 2019 TPE.

Table 1. Availability of Environmental Section and its Number of Statements.

\begin{tabular}{lll}
\hline Political party & $\begin{array}{l}\text { Is an } \\
\text { environmental } \\
\text { section available? }\end{array}$ & $\begin{array}{l}\text { Number of statements on } \\
\text { environment from the } \\
\text { available section }\end{array}$ \\
\hline DPP & N/A & 0 \\
UDF & YES & 0 \\
MCP & YES & 6 \\
UP & N/A & 0 \\
UTM & YES & 7 \\
MMD & - & - \\
Independent & - & - \\
\hline
\end{tabular}

\section{Discussion}

The presidential position during the May, 2019 TPE attracted a total of seven candidates who labored to sell their party, party coalition or individual manifesto with only one out of seven, being an independent candidate. From the seven presented manifestos, this study investigated five (5) manifestos from parties and individuals that contested. An observation from the five investigated manifestoes revealed more than 50 chapters/sections that were presented as main focal points in the manifestoes whose average mean was 11.4 and a range of 20 being presented by the parties in the 2019 TPE.

Out of the total number of chapters presented by the five parties, $44 \%$ was by the DPP followed by the UP with the least being $9 \%$ by UTM and UDF parties respectively. There were more than 1309 statements that were presented in the 2019 TPE from the five parties investigated with an average mean of 261.8 statements and a range of 198 . Of all the statements presented, $26.3 \%$ was by MCP followed by the DPP (23.1\%) and the least being $11.3 \%$ presented by the UP.

The manifestos presented revealed that only $60 \%$ of the presented manifestos had a section specifically meant to address issues on the environment. The other $40 \%$ had scanty or no specific section on the environment imbedded in their manifestos. But in one way or the other some commitments were made indirectly through other section such as Agriculture, Energy and Mining, Economic growth, Land Management, Food and Nutritional Security, Water and Sanitation as well as Resource Management and others relevant.

Of the parties that had a section on the environment, less than ten (10) statements were made as commitments by the parties meant to help resolve and mitigate environmental catastrophes as compared to other sectors like Agriculture, Public Sector Reforms, Trade Commerce and Industrial development, Education, Gender and Social Inclusion, Social Protection, foreign Policy, Health as well as Mining and Development. For example, under the mining and development, UTM made twenty-two (22) commitments against seven (7) statements of commitment on the environment in its manifesto while UDF on one hand had a section on the environment but with no statement of commitment at all on it.

Comparatively from the presented statements, environmental commitments made were less than $3 \%$ of the total presented by the parties in the manifesto. For example, MCP had a total of 344 statements made with only 6 statements presented in a section for the environment representing $1.744 \%$ of the total statements made while UTM had $2.448 \%$.

\section{Conclusion}

Environmental degradation is a concern worldwide. In a country where environmental issues have taken center stage in public opinion, citizens are likely to be interested in a party with policies in its manifesto that favor the environment. 
Considering political parties to be opportunists, they are likely to develop/modify their political manifestos to suit public opinion. The goal is to attract votes and political parties whose manifestos are lacking environmental policies are likely to lose votes.

The importance of having environmental adherences within political partys' manifestos need to affirmatively be considered by political parties. Countries and governments are attached to numerous international treaties on the environment that are meant to foster total compliance in working together with other countries to address vital issues that are transboundary or global in nature such as climate change, air pollution, ozone layer protection as well as ocean pollution [16].

This is in the belief that quality of any particular country' environment depend not only on what the country does at home but also on activities done beyond its borders [16]. As such, political parties must show responsibility way from the start of their manifesto development by making sure inclusiveness of such environmental statements.

Much as most parties incorporated such mitigating strategies within other sections such as agriculture, energy and mining as well as economic development and others, it is necessary to have a standalone section or subsection, in fact a complete chapter that underlays proper commitments of a particular party in taking head on responsibilities on issues that deals with the environment. This signifies how committed potential governments but also parties are on international treaties.

The 2019 TPE has therefore shown that parties have little to no consideration at all on issues of the environment into priority. In line with Holn et al., (2015), the belief that human preferences, practices and actions are the main drivers of global environmental change in the 21 st century, must be a center of concern for the public and those that intend to take over full responsibility of public offices [11].

This lack of much commitment on environmental issues by political parties in their manifestos in the 2019 TPE may be on one hand an indication that there is less public opinion on environmental issues despite these issues taking a global center stage and affecting citizens' everyday lives. This lack of public concern could be due to lack of awareness on the seriousness of environmental issues.

On the other hand, it might also be that there are other concerns that seem more important than environmental issues that the public would love sorted out first such as issues of health, education, agriculture as well as economic development. Furthermore, it could be that these documents are being prepared at the speed of light making it difficult to make proper consultations on matters of public interest among others. Arrow et al. indicates that in a country people would begin giving environmental issues a greater interest when they have attained a high standard of living [2].

This is a fact and our parties need to properly set these preferences as commitments for action before time not only when either they are in power or after attaining a high standard of living but also when making such intentions through their manifestos. Considerations to intensify the placement of environmental chapters or section with disclosures in these party manifestos in order to inform better policy developments as indicators of performance on the environment but also a devotion to international treaties once implemented could be of greater thought.

\section{References}

[1] Abazović, D., \& Mujkić, A. (2015). Political will: a short introduction Case study-Bosnia and Herzegovina. Bosnia: Friedrich-Ebert-Stiftung (FES).

[2] Arrow, K., Bolin, B., Costanza, R., Dasgupta, P., Folke, C., Holling, C., \&..., D. (1995). Economic Growth, Carrying Capacity, and the Environment. Ecological Economics, 15 (2), 91-95.

[3] Birchall, S. (2014). Termination Theory and National Climate Change Mitigation Programs: the Case of New Zealand. Review of Policy Research, 31 (1), 38-59.

[4] Brulle, R., Carmichael, J., \& Jenkins, J. (2012). Shifting Public Opinion on Climate Change: an Empirical Assessment of Factors Influencing Concern Over Climate Change in the U.S., 2002-2010. Climatic Change, 114 (2), 169-188.

[5] DTA. (2014). DTA of Namibia, 2014 Election Manifesto. DTA-Namibia.

[6] EAD. (2010). Malawi State of Environment and Outlook Report; Environment for Sustainable Economic Growth. Lilongwe: Environmental Affairs Department.

[7] Eder, N., Jenny, M., \& Müller, W. C. (2017). Manifesto functions: How party candidates view and use their party's central policy document. Journal of Electoral Studies, 75-85. doi: 10.1016/j.electstud.2016.11.011.

[8] Elischer, S. (2012). Measuring and comparing party ideology in nonindustrialized societies: taking party manifesto research to Africa. Democratization, 19 (4), 642-667.

[9] EPP. (2019). European Peoples Party. Retrieved August 7, 2019, from European Peoples Party website: https://www.epp.eu/files/uploads/2019/05/EPP-MANIFESTO -2019.pdf.

[10] Guha, A., \& Joe, E. T. (2019, March 2). 'Environment' in the Election Manifestos. Economic and Political Weekly, 54 (9).

[11] Holm, P., Adamson, J., Huang, H., Kirdan, L., Kitch, S., McCalman, I.,... Wehner, K. (2015). Humanities for the Environment-A Manifesto for Research and Action. Journal of Humanities, 4, 977-992. doi: 10.3390/h4040977.

[12] HR. (2019). 2019 Cyclone Idai-Situation Report 2. Humanity Road. Humanity Road.

[13] Michallet, B., Gaeta, G. L., \& Facchini, F. (2015). Greening Up or Not? The Determinants Political Parties' Environmental Concerns: An Emperical Analysis Based on European Data (1970-2008). Halshs-01154006.

[14] Mpesi, A. M. (2011, March 22). Special Section: On Malawi Political Parties and their Manifestos: Inferring Party Policy Positions in Malawi since 1994. Altmetric, 38 (1), 25-41.

[15] Neumeyar, E. (2004). The Environment, Left Wing Political Oriantation and the Ecological Economics. Ecological Economics, 54 (3-4), 167-175. 
[16] OAGC. (2004). The Report of the Commissioner of the Environment and Sustainable Development to the House of Commons. Canada: The Office of the Auditor General of Canada (OAGC).

[17] OECD. (June, 2012). Green Growth and Developing Countries: CONSULTATION DRAFT. OECD. Retrieved June 13, 2020, from

https://www.oecd.org/dac/environment-development/5055911 6.pdf.

[18] Post, L. A., Raile, A. N., \& Raile, E. D. (2010). Defining Political Will. Politics and Policy, 38 (4), 653-676.
[19] Rollinson, S. (2010, Winter). Changing Dynamics of Environmental Politics in Britain: a case study of the UK Climate Change Act. POLIS Journal, 3.

[20] Ryan, D. (2017). Politics and Climate Change: Exploring the Relationship Between Political Parties and Climate Issues in Latin American. Ambiente \& Sociedade, 20 (2), 271-286.

[21] UNESCAP. (n.d.). www.unescap.org. Retrieved March 26, 2019, from UNESCAP Website: https://www.unescap.org/sites/default/files/CH08.PDF.

[22] W. E. F. (2012). Global Risks 2012. Cologny, Geneva. 